\title{
A SIMULATION MODEL FOR COMPUTING THE LOADS GENERATED AT LANDING SITE DURING HELICOPTER TAKE-OFF OR LANDING OPERATION
}

\author{
Jarosław Stanisławski \\ Institute of Aviation, \\ Al. Krakowska 110/114, 02-256 Warsaw, Poland \\ jaroslaw.stanislawski@ilot.edu.pl
}

\section{Summary}

The paper presents simulation method and results of calculations determining behavior of helicopter and landing site loads which are generated during phase of the helicopter take-off and landing. For helicopter with whirling rotor standing on ground or touching it, the loads of landing gear depend on the parameters of helicopter movement, occurrence of wind gusts and control of pitch angle of the rotor blades. The considered model of helicopter consists of the fuselage and main transmission treated as rigid bodies connected with elastic elements. The fuselage is supported by landing gear modeled by units of spring and damping elements. The rotor blades are modeled as elastic axes with sets of lumped masses of blade segments distributed along them. The Runge-Kutta method was used to solve the equations of motion of the helicopter model. According to the Galerkin method, it was assumed that the parameters of the elastic blade motion can be treated as a combination of its bending and torsion eigen modes. For calculations, data of a hypothetical light helicopter were applied. Simulation results were presented for the cases of landing helicopter touching ground with different vertical speed and for phase of take-off including influence of rotor speed changes, wind gust and control of blade pitch. The simulation method may help to define the limits of helicopter safe operation on the landing surfaces.

Keywords: helicopter, landing site, landing gear loads.

\section{INTRODUCTION}

Helicopters, due to an ability of hover and landing on the limited area, from early days of their deployment, were involved in rescue operations. Among the first civil air rescue service was Swiss Rega which in 1952 commenced helicopter rescue operation [1]. In Poland the SM-1 helicopter for the first time was introduced to civil rescue service in 1958 (Lotnictwo Sanitarne) [2]. The quick development of helicopter usage in rescue and medical missions with aim to shorten the time of patient transport 
led to application of specialized heliports localized on ground in vicinity of hospitals or on roof-top of hospital buildings.

To preserve conditions of safety helicopter operations, the set of rules including specifications on the planning, design and operation of heliports were collected in ICAO (International Civil Aviation Organization) documents [3]. According to safety demands, the structure of elevated heliport should withstand all the forces likely to act when a helicopter lands including an impact load of $2.5 \times \mathrm{MTOM}$ (maximum take-off mass) in the case of emergency landing. American FAA (Federal Aviation Administration) also introduced regulations concerning heliport design [4] and issued updated advisory circulars [5]. In Poland a considerable increase of heliport number is observed as result of law regulations which demanded introduction of heliport as a part of hospital emergency department [6]. Due to lack of place in urban area the heliports were often built in form of elevated helipads at rooftop of buildings. After some years of relatively intensive helicopter operations, the harmful influence of vibrations generated by helicopters could be noticed which caused damages of building structures beneath the roof helipad [7]. In new edition of UK CAA (civil Aviation Authority) document[8], standards for helicopter landing areas at hospitals are formulated which demand prediction of the flow field around a heliport including effects of local turbulence generated by obstacles and other buildings in environment.

The subject of some recent works at the Institute of Aviation was concentrated on the CFD analysis of safety of helicopter operations over elevated helipads including wind direction influence on spatial field of flow in urbanized area [9] and influence of pressure and velocity generated by rotor wake on surfaces of the nearby buildings [10]. The two-bladed rotor of diameter equal $7.9 \mathrm{~m}$ and set of microphones were applied in experimental research of rotor induced pressure pulsation on surface located beneath rotor [11]. The particle image velocimetry method (PIV) was involved in measurements of dynamic flow in hover condition generated by model of rotor of $0.7 \mathrm{~m}$ diameter [12]. The pressure and velocity measurements were compared with the CFD analysis for the case of real rotor in test cage and the case of model rotor.

The present paper is focused on application an simulation method for calculation the dynamic forces at surface of landing site which are generated by landing gear of helicopter during take-off or landing operations. The helicopter is modeled by fuselage and gearbox treated as stiff bodies and rotor with elastic blades. The helicopter is assumed to be supported on landing gear consists of four spring-damper units. Data of hypothetical light helicopter of 1,000 kg mass are used for simulation calculations. The results of take-off and landing simulations may help to determine not-defined in regulations, the variable loads of landing gears which can be transmitted to elements of construction supporting the surface of helipad.

\section{SIMULATION MODEL}

The model of helicopter applied for simulation calculations consists of fuselage and transmission gearbox treated as stiff bodies and elastic blades of the main rotor. The helicopter is assumed to stay on helipad with whirling rotor to simulate the initial phase of take-off including increase of rotor speed or to simulate the part of landing maneuver with moment of touch-down and following decrease of rotor rotational speed. The helicopter fuselage is supported on the elastic landing gear which is modeled by set of spring and damper units (Fig.1). Similarly, the flexible connections of transmission gearbox and fuselage are provided by set of spring and damper elements. 


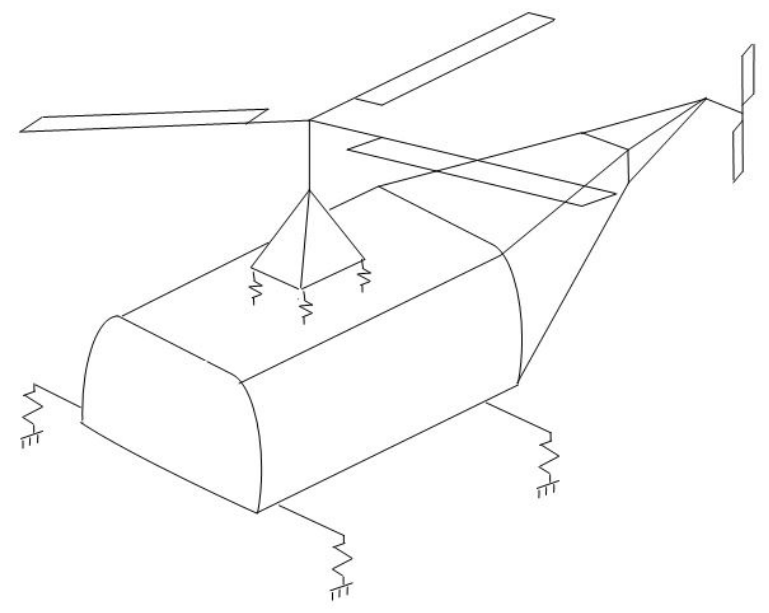

Fig.1. Scheme of helicopter on landing gear units - dampers, lateral and longitudinal springs not shown for clarity [author]

The blades of main rotor are treated as the elastic axes with lumped masses of blade segments distributed along radius of each blade (Fig.2). The forces acting on helipad surface during take-off or landing operations depend mainly on mass of helicopter and on parameters of its motion. Also, occurrence of wind gusts and control of rotor blade pitch may affect the value of loads which act on landing surface. Generated at the rotor blades aerodynamic and inertial loads have impact on bending and torsion deflections of blades and their flap, lag and pitch motion. The rotor loads cause motion of fuselage supported on the flexible landing gear which mutually affects motion and loads of the rotor blades. Introduction to the model of rotor-fuselage system the effects of rotor speed changes, wind gusts and control of blade pitch angle allow to define the range of forces generated on landing surface in different conditions of helicopter touch-down or take-off operations.

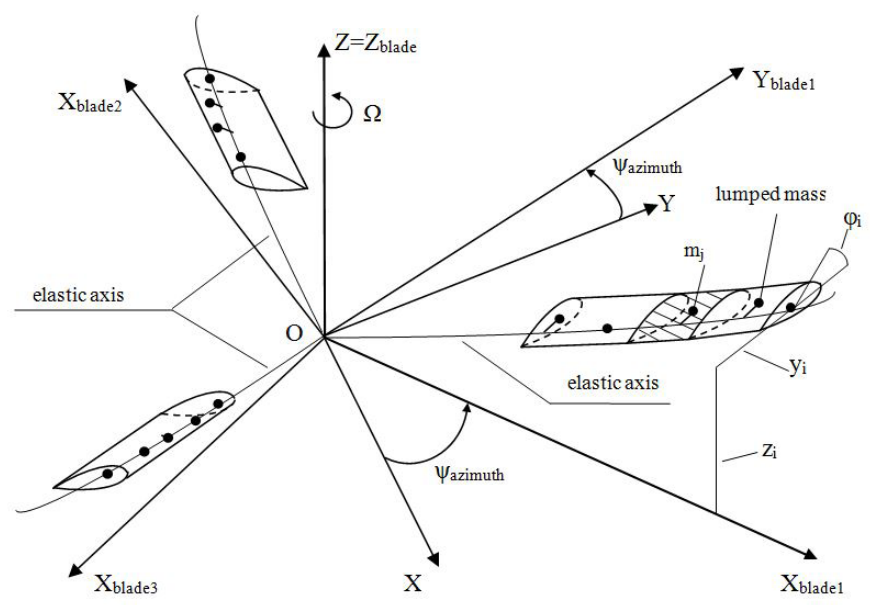

Fig.2. Model of rotor blades with lumped masses along elastic axes [author] 
The mathematical model of rotor-fuselage system includes equations of motion of elastic blades and equations of motion of fuselage and gearbox which are treated as stiff bodies with six degrees of freedom and with ability of linear and rotational displacements due to their elastic support. The equations of motion of elastic blades are formulated taking into account torsion and bending in-plane and out-of-plane blade deflections. According to Galerkin's method the blade deflections are assumed to be equal to the sums of component deformations corresponding to applied blade eigen modes. The equations of motion for fuselage, gearbox and rotor blades can be solved applying the Runge-Kutta method. For the multi-bladed model of the main rotor the blade loads and parameters of blade motion are calculated for each blade at their different azimuth positions.

The equations of motion of blade elastic axis can be formulated applying Lagrange's equation:

$$
\frac{d}{d t}\left(\frac{\partial T}{\partial \dot{q}_{i}}\right)-\frac{\partial T}{\partial q_{i}}+\frac{\partial U}{\partial q_{i}}=Q_{i} \mathrm{i}=1, \ldots, \mathrm{n}(1)
$$

Potential energy $U$ of blade which is mutually bent out-of-plane, bent in-plane and twisted is equal:

$$
U=\frac{1}{2} \int_{0}^{R} E J_{Y}\left(\frac{d^{2} z}{d x^{2}}\right)^{2} d x+\frac{1}{2} \int_{0}^{R} E J_{Z}\left(\frac{d^{2} y}{d x^{2}}\right)^{2} d x+\frac{1}{2} \int_{0}^{R} G J_{X}\left(\frac{d \varphi}{d x}\right)^{2} d x
$$

Kinetic energy $\mathrm{T}$ of blade elastic axis is as follows:

$$
T=\frac{1}{2} \int_{0}^{R} m(x) V_{Y}^{2}(x) d x+\frac{1}{2} \int_{0}^{R} m(x) V_{Z}^{2}(x) d x+\frac{1}{2} \int_{0}^{R} I_{X}(x) \dot{\varphi}^{2}(x) d x
$$

For rotating blade, the centrifugal forces generate stiffening effects which influence on blade bending. Due to the centrifugal force, the corrections of cross-section loads which act on $d x$ segment are as follows:

where

$$
\begin{gathered}
\text { - in-plane } p_{Y_{\Omega}}=\frac{d}{d x}\left(N \frac{d y}{d x}\right)-m(x) \Omega^{2} y \\
\text { - out-of-plane } \mathrm{p}_{\mathrm{Z}_{\Omega}}=\frac{\mathrm{d}}{\mathrm{dx}}\left(\mathrm{N} \frac{\mathrm{dz}}{\mathrm{dx}}\right)
\end{gathered}
$$

$N=\int_{r}^{R} m(x) \Omega^{2} x d x$ - the centrifugal force at cross-section located at distance $r$ from the rotor shaft axis.

Taking into account expressions $(1) \div(5)$, the equations of motion of elastic rotor blade can be defined as follows:

- for in-plane bending

$$
\int_{0}^{R} m(x) \ddot{y} d x+\int_{0}^{R}\left\{\frac{d^{2}}{d x^{2}}\left[E J_{Z}\left(\frac{d^{2} y}{d x^{2}}\right)\right]-\frac{d}{d x}\left(N \frac{d y}{d x}\right)+m(x) \Omega^{2} y\right\} d x=\int_{0}^{R}\left(F_{Y_{E X T}}-F_{Y_{I N}}\right) d x
$$


- for out-of-plane bending

$$
\int_{0}^{R} m(x) \ddot{z} d x+\int_{0}^{R}\left\{\frac{d^{2}}{d x^{2}}\left[E J_{Y}\left(\frac{d^{2} z}{d x^{2}}\right)\right]-\frac{d}{d x}\left(N \frac{d z}{d x}\right)\right\} d x=\int_{0}^{R}\left(F_{Z_{E X T}}-F_{Z_{I N}}\right) d x
$$

- for torsion

$$
\int_{0}^{R} I_{X}(x) \ddot{\varphi} d x+\int_{0}^{R} \frac{d}{d x}\left[G J_{X}\left(\frac{d \varphi}{d x}\right)\right] d x=\int_{0}^{R}\left(M_{T_{E X I}}(x)-M_{T_{L N}}(x)\right) d x
$$

where

$F_{Y_{E X T}}, F_{Z_{E X T}}, M_{T_{E X T}}$ - shear forces and torsion moment of external loads acting on segment $d x$ of elastic axis, $F_{Y_{N}}, F_{Z_{N}}, M_{T_{N}}$-inertial forces and torsion moment of inertial loads with respectively extruded following components $m \ddot{y}, m \ddot{z}, I_{X} \ddot{\varphi}$.

According to Galerkin's method, the deflections of the elastic axis $y, z, \varphi$ are equal to the sum of component deformations of the considered blade eigen modes:

$$
\begin{aligned}
& y(x, t)=\sum_{n 1=1}^{N 1} \rho_{n 1}(t) y_{n 1}(x) \\
& z(x, t)=\sum_{n 2=1}^{N 2} \delta_{n 2}(t) z_{n 2}(x) \\
& \varphi(x, t)=\sum_{n 3=1}^{N 3} \eta_{n 3}(t) \varphi_{n 3}(x)
\end{aligned}
$$

where

$y_{n 1}, z_{n 2}, \varphi_{n 3}$ - eigen modes in-plane bending, out-of-plane bending and torsion respectively;

$\rho_{n 1}, \widehat{\delta_{n 2}}, \eta_{n 3}$ - time dependent shares of each eigen mode;

$N 1, N 2, N 3$ - the numbers of considered bending and torsion eigen modes.

Applying orthogonality condition of the eigen modes, the equations of blade motion $(6) \div(8)$ can be transformed into sets of equations $(12) \div(14)$, where each equation concerns to one of the considered eigen mode of the blade:

$$
\begin{aligned}
& \ddot{\rho}_{n 1}+\rho_{n 1} p_{n 1}^{2}=Q_{Y_{n 1}}, n 1=1, \ldots, N 1 \\
& \ddot{\delta}_{n 2}+\delta_{n 2} f_{n 2}^{2}=Q_{Z_{n 2}}, n 2=1, \ldots, N 2 \\
& \ddot{\eta}_{n 3}+\eta_{n 3} v_{n 3}^{2}=Q_{\varphi_{n 3}}, n 3=1, \ldots, N 3
\end{aligned}
$$

where

$Q_{Y_{n 1}}, Q_{Z_{n 2}}, Q_{\varphi_{n 3}}$ - generalized forces for eigen modes of the blade.

At each azimuthal position of blade on the rotor disk, the aerodynamic forces acting on the blade segments are calculated using the blade element theory. The local angle of attack depends on temporary blade pitch and on conditions of the cross-section airflow: 


$$
\alpha=\varphi_{g t w}+\varphi-\operatorname{arctg}\left(\frac{v_{Z}}{v_{X}}\right)
$$

where

$\varphi_{\text {gtw }}$ - geometric twist,

$\mathrm{y}_{Z}, v_{X}$ - vertical and horizontal components of airflow,

$\varphi$ - temporary pitch angle due to deformations and applied control.

Pitch angle of a blade element is determined as follows:

$$
\varphi=\varphi_{o}+\varphi_{x} \cos (\omega t)+\varphi_{y} \sin (\omega t)+\varphi_{d e f}-\kappa \beta
$$

where

$\varphi_{o}$ - collective control angle,

$\varphi_{x}, \varphi_{y}$ - cyclic control angle as result of roll and pitch deflection of the swashplate,

$\varphi_{\text {def }}$ - angle of torsion deformation at cross-section of blade,

$K$ - coefficient of flap-pitch coupling

$\beta$ - temporary blade flapping angle at horizontal hinge of rotor head.

The inertial forces acting on the lumped mass $m_{i}$ of blade segment can be determined defining its the position $\bar{r}_{m i}$, velocity $\bar{V}_{m i}$ and acceleration $\bar{p}_{m i}$ in the fixed coordinate system $\mathrm{O}_{\mathrm{gn}} \mathrm{X}_{\mathrm{gn}} \mathrm{Y}_{\mathrm{gn}} \mathrm{Z}_{\mathrm{gn}}$ :

$$
\bar{r}_{m i}=\bar{r}_{f u s}+\bar{r}_{\text {gear }}+\bar{r}_{h u b}+\bar{r}_{b l}
$$

where

$\bar{r}_{\text {fus }}$ - position of fuselage mass center $\mathrm{O}_{\mathrm{f}}$,

$\bar{r}_{\text {gear }}$ - gearbox mass centre $\mathrm{O}_{\mathrm{gb}}$ position relative to the fuselage point $\mathrm{O}_{\mathrm{f}}$,

$\bar{r}_{h u b}$ - centre of rotor hub $\mathrm{O}_{\mathrm{h}}$ position relative to the gearbox mass center $\mathrm{O}_{\mathrm{gb}}$,

$\bar{r}_{b l}$ - position of lumped mass $m_{i}$ of blade segment relative to center of rotor hub $\mathrm{O}_{\mathrm{h}}$.

The expression for velocity of mass $m_{i}$ of blade segment can be derived after differentiation of equation (17):

$$
\bar{V}_{m i}=\bar{V}_{\text {fus }}+\Delta \dot{\bar{\varphi}}_{\text {fus }} \times\left(\bar{r}_{\text {gear }}+\bar{r}_{h u b}+\bar{r}_{b l}\right)+\frac{\partial^{\prime}}{\partial t} \bar{r}_{\text {gear }}+\Delta \dot{\bar{\varphi}}_{\text {gear }} \times\left(\bar{r}_{h u b}+\bar{r}_{b l}\right)+\frac{\partial^{\prime \prime \prime}}{\partial t} \bar{r}_{b l}+\bar{\Omega}_{M R} \times \bar{r}_{b l}
$$

where

$\bar{V}_{f u s}$ - linear velocity of fuselage mass center $\mathrm{O}_{\mathrm{f}}$ relative to ground,

$\Delta \dot{\bar{\varphi}}_{\text {fus }}$ - angular velocity of fuselage,

$\frac{\partial^{\prime}}{\partial t} \bar{r}_{\text {gear }}$ - linear velocity of gearbox mass center $\mathrm{O}_{\mathrm{gb}}$ relative to fuselage mass center $\mathrm{O}_{\mathrm{f}}$,

$\Delta \dot{\bar{\varphi}}_{\text {gear }}$ - angular velocity of gearbox relative to fuselage,

$\frac{\partial^{\prime \prime \prime}}{\partial t} \bar{r}_{b i}$ - velocity of mass of blade section relative to hub center $\mathrm{O}_{\mathrm{gb}}$ due to deflections of elastic blade axis, $\bar{\Omega}_{M R}$ - angular velocity of main rotor.

Derivative of equation (18) against time yields acceleration of blade segment mass $m_{i}$ with intro- 
duced effects of elasticity of landing gear, elements connecting gearbox and elasticity of rotor blade:

$$
\begin{aligned}
\bar{p}_{m i}= & \bar{p}_{\text {fus }}+\Delta \ddot{\bar{\varphi}}_{\text {fus }} \times\left(\bar{r}_{\text {gear }}+\bar{r}_{\text {hub }}+\bar{r}_{b l}\right)+\Delta \dot{\bar{\varphi}}_{\text {fus }} \times\left[\Delta \dot{\bar{\varphi}}_{\text {fus }} \times\left(\bar{r}_{\text {gear }}+\bar{r}_{\text {hub }}+\bar{r}_{b l}\right)\right]+2 \Delta \dot{\bar{\varphi}}_{\text {fus }} \times\left(\frac{\partial^{\prime}}{\partial t} \bar{r}_{\text {gear }}\right)+ \\
& +2 \Delta \dot{\bar{\varphi}}_{\text {flis }} \times\left[\Delta \dot{\bar{\varphi}}_{\text {gear }} \times\left(\bar{r}_{\text {hub }}+\bar{r}_{b l}\right)\right]+2 \Delta \dot{\bar{\varphi}}_{\text {fus }} \times\left(\frac{\partial^{\prime \prime \prime}}{\partial t} \bar{r}_{b l}+\bar{\Omega}_{M R} \times \bar{r}_{b l}\right)+\frac{\partial^{\prime 2}}{\partial t^{2}} \bar{r}_{\text {gear }}+ \\
& +\Delta \ddot{\bar{\varphi}}_{\text {gear }} \times\left(\bar{r}_{\text {hub }}+\bar{r}_{b l}\right)+\Delta \dot{\bar{\varphi}}_{\text {gear }} \times\left[\Delta \dot{\bar{\varphi}}_{\text {gear }} \times\left(\bar{r}_{\text {hub }}+\bar{r}_{b l}\right)\right]+2 \Delta \dot{\bar{\varphi}}_{\text {gear }} \times\left(\frac{\partial^{\prime \prime \prime}}{\partial t} \bar{r}_{b l}+\bar{\Omega}_{M R} \times \bar{r}_{b l}\right)+ \\
& +\frac{\partial^{\prime \prime 2}}{\partial t^{2}} \bar{r}_{b l}+\dot{\bar{\Omega}}_{M R} \times \bar{r}_{b l}+2 \bar{\Omega}_{M R} \times \frac{\partial^{\prime \prime \prime}}{\partial t} \bar{r}_{b l}+\bar{\Omega}_{M R} \times\left(\bar{\Omega}_{M R} \times \bar{r}_{b l}\right)
\end{aligned}
$$

where

$\bar{p}_{f i t .}$ - linear acceleration of fuselage mass center $\mathrm{O}_{\mathrm{f}}$ relative to ground,

$\Delta \overline{\bar{\varphi}}_{\text {fus }}$ - angular acceleration of fuselage,

$\frac{\partial^{\prime 2}}{\partial t^{2}} \bar{r}_{\text {gear }}$ - linear acceleration of gearbox mass center $\mathrm{O}_{\mathrm{gb}}$ relative to fuselage mass center $\mathrm{O}_{\mathrm{f}}$

$\Delta \ddot{\bar{\varphi}}_{\text {gear }}$ - angular acceleration of gearbox relative to fuselage,

$\frac{\partial^{\prime \prime \prime 2}}{\partial t^{2}} \bar{r}_{b l}$ - linear acceleration of lumped mass relative to centre of rotor hub $\mathrm{O}_{\mathrm{h}}$.

For the fuselage and gearbox which as stiff bodies can move on their elastic supports, the equations of motion formulated in movable coordination systems fixed to fuselage or gearbox mass center are as follows:

- force equation

$$
m_{s b}\left(\frac{\partial \bar{V}_{s b}}{\partial t}+\bar{\omega}_{s b} \times \bar{V}_{s b}\right)=\bar{F}_{s b}, s b=\text { fus, gear }
$$

- moment equation

$$
\frac{\partial K_{s b}}{\partial t}+\bar{\omega}_{s b} \times \bar{K}_{s b}=\bar{M}_{s b}, j=f, g b
$$

where index $s b=f u s$ is for fuselage and $s b=$ gear for gearbox respectively.

The external forces $\bar{F}_{s b}$ and moments $\bar{M}_{s b}$ in equation (20) and (21) include components of gravity forces and reactions of other units of helicopter:

- for fuselage

$$
\begin{gathered}
\overline{F_{f u s}}=\bar{T}_{R L G}+\overline{G_{f u s}}+\overline{F_{R G B}}+\bar{F}_{T R} \\
\overline{M_{\text {fus }}}=\bar{T}_{R L G} \times \bar{r}_{R L G}+\bar{F}_{R G B} \times \bar{r}_{R G B}+\bar{F}_{T R} \times \bar{r}_{T R}+\bar{M}_{T R}
\end{gathered}
$$

where 
$\bar{T}_{R L G}$ - reactions of landing gear units,

$\bar{G}_{f u s}$ - fuselage gravity force,

$\bar{F}_{R G B}$ - reactions of the gearbox at connections with fuselage,

$\bar{F}_{T R}, \bar{M}_{T R}$ - forces and moments of the tail rotor,

$\bar{r}_{R L G}, \bar{r}_{R G B}, \bar{r}_{T R}$ - arms of forces for landing gear, gearbox and tail rotor respectively.

- for gearbox

$$
\begin{gathered}
\bar{F}_{\text {gear }}=\bar{T}_{R F U S}+{\overline{G_{\text {gear }}}}+\bar{F}_{H U B} \\
\overline{M_{\text {gear }}}=\bar{T}_{R F U S} \times \bar{r}_{R F U S}+\bar{F}_{H U B} \times \bar{r}_{H U B}+\bar{M}_{H U B}
\end{gathered}
$$

where

$\bar{T}_{R F U S}$ - reaction forces at fuselage-gearbox connections acting on gearbox,

$\bar{G}_{\text {gear }}$ - gearbox gravity force,

$\bar{F}_{H U B}, \bar{M}_{H U B}$ - forces and moments of the rotor hub,

$\bar{r}_{R F U S}, \bar{r}_{H U B}$ - arms of forces for reactions of fuselage and rotor hub respectively.

The reaction forces of landing gear $\bar{T}_{R L G}$ at connections with fuselage and reaction forces at fuselage-gearbox connections acting can be expressed due to linear and angular components of fuselage and gearbox displacements and velocities.

Solving the set of equations of motion of fuselage, gearbox and elastic rotor blades with the time step equal to $1^{\circ}$ degree change of rotor blade azimuthal position, for range extended over one hundred of rotor revolutions, enables to simulate behavior of helicopter during landing or take-off operations.

\section{RESULTS OF CALCULATIONS}

In the considered cases, the calculations were performed applying data of light helicopter of $1000 \mathrm{~kg}$ mass for landing or take-off operations when elements of landing gear were in contact with ground or surface of helipad. The time of simulations was extended to the range of 200 revolutions of the main rotor. The presented results of calculations refer to the following cases for helicopter touching and standing on landing area with rotating rotor which generates thrust less than weight of rotorcraft:

- landing with vertical speed equal $1 \mathrm{~m} / \mathrm{s}$ and following high rate of rotor speed decrease (Fig.3a $\div 6 \mathrm{a}$ );

- soft landing with vertical speed $0.1 \mathrm{~m} / \mathrm{s}$ and high rate of rotor speed decrease (Fig. $3 \mathrm{~b} \div 6 \mathrm{~b})$;

- landing with moderate vertical speed $1 \mathrm{~m} / \mathrm{s}$ and slow rate of rotor speed decrease (Fig.6c,7,8);

- case before take-off with rotor speed increase, wind gust and increase of blade collective pitch (Fig.9 $\div 13$ ). 

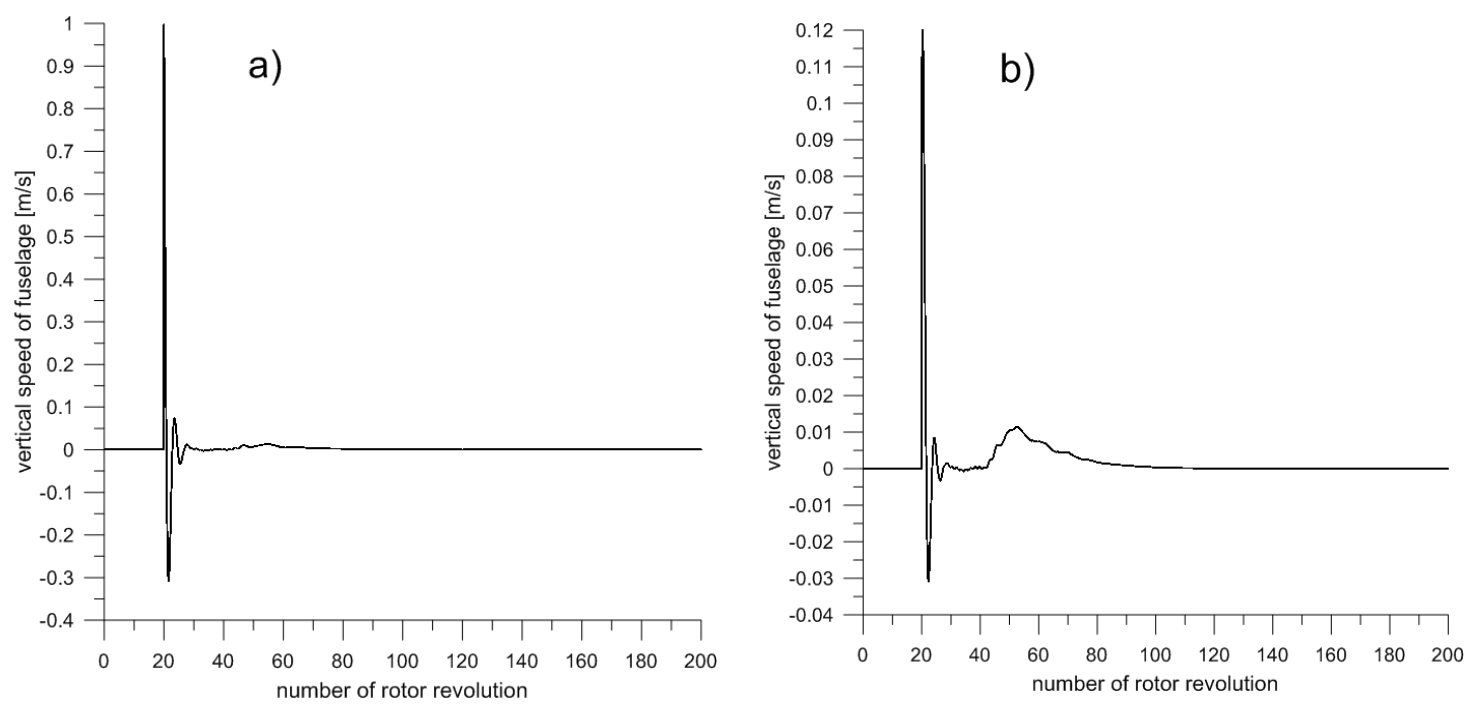

Fig.3. Time-runs of vertical speed of mass centre of fuselage for helicopter landing with different value of vertical speed at the moment of touch down the ground: a) landing with moderate vertical speed equal $1 \mathrm{~m} / \mathrm{s}$; b) case of soft landing with slow vertical speed of $0.1 \mathrm{~m} / \mathrm{s}$ [author]
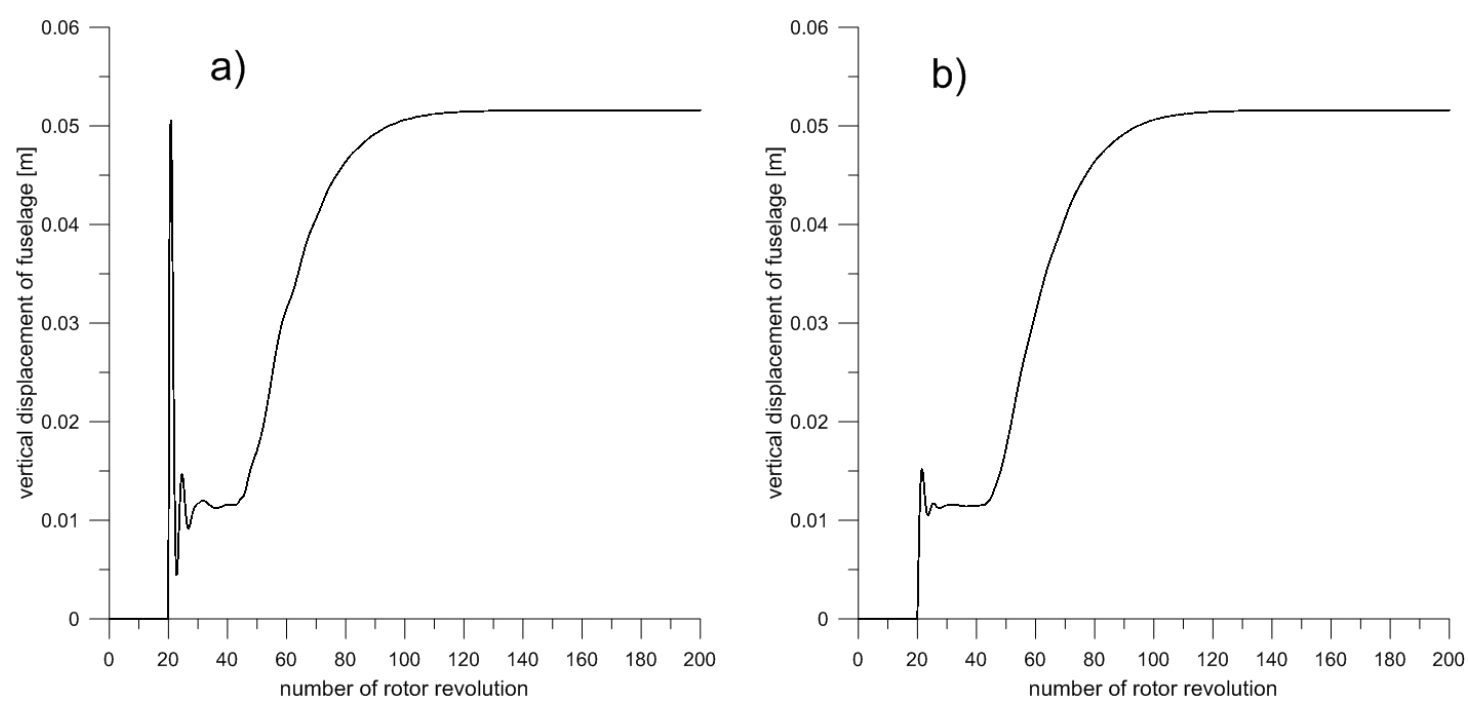

Fig.4. Vertical displacements of mass centre of the fuselage helicopter during landing with different vertical speed at the moment of touch down: a) the case of the initial vertical speed equal $1 \mathrm{~m} / \mathrm{s}$; b) soft landing with slow vertical speed of $0.1 \mathrm{~m} / \mathrm{s}$ [author]

The each case of simulation was started with initial phase of the first 20 rotor revolutions for the decay of the initial conditions of rotor blades motion with axis of rotor kept in steady position in space. Then after the 20th rotor revolution the fuselage and gearbox motions were started as the result of deflections of the landing gear and deflections of the fuselage-gearbox connections. For the cases of landing the initial vertical speed of helicopter was introduced. Additionally at that moment the helicopter 
was assumed to touch the landing surface with non-deflected landing gear. Next after the 40th rotor revolution, the rotor speed was decreased until it reached the assumed lower value which then was kept constant to the end of simulation.

In Fig. $3 \div$ Fig. 6 are presented the comparisons of parameters of fuselage motion, landing gear forces and rotor blade motion for the case of landing with moderate value of vertical speed and the case with slow vertical speed at the moment of helicopter touchdown. The landing with the higher value of vertical speed (Fig.3a) results just after touchdown in larger fuselage displacements (Fig.4) and greater landing gear loads (Fig.5). It can be noticed that during dynamic phase of diminishing the helicopter speed, the vertical component of force acting on unit of landing gear (Fig.5a) reaches nearly the double value in comparison to the level of landing gear force for the steady conditions of simulation after the 100th revolution of rotor. More gradual increase of landing gear force can be observed for the phase of reducing the rotor thrust between the 40th and the 100 th revolution due to the quick drop of rotor speed (Fig.5).
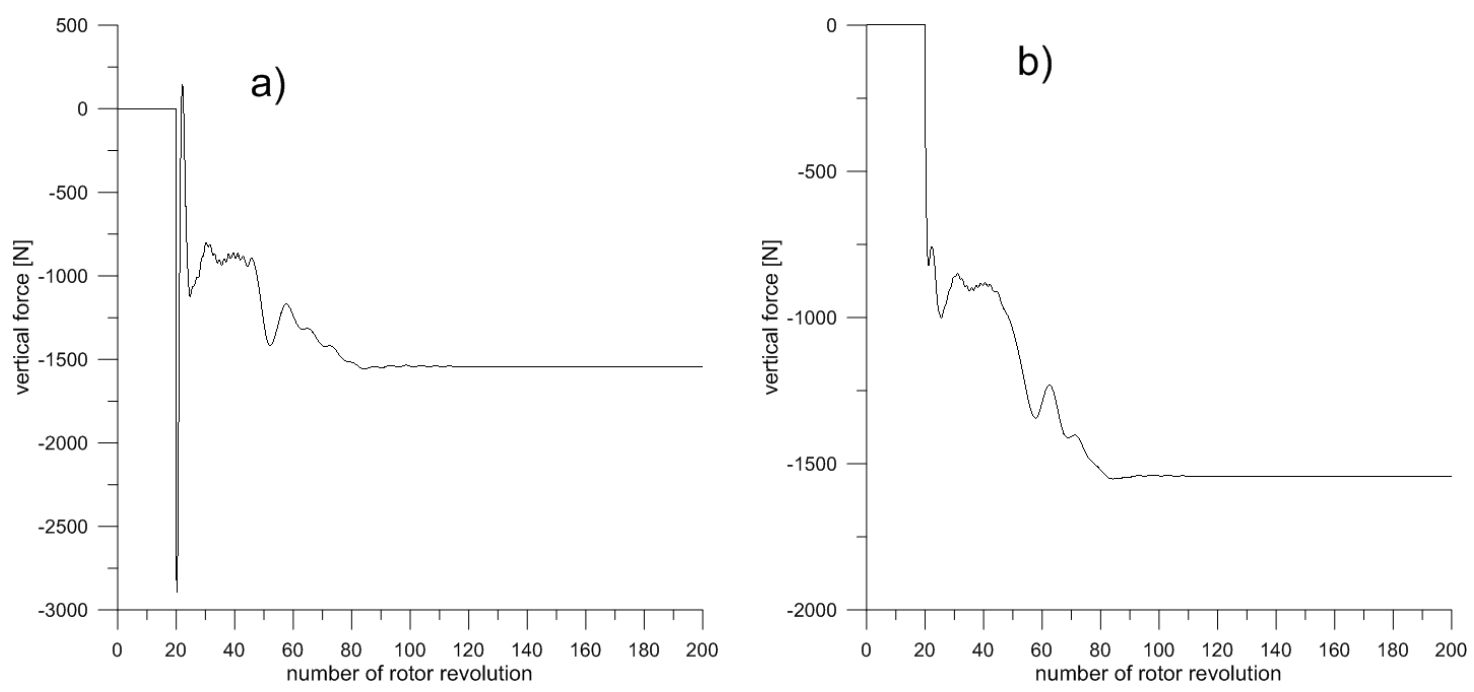

Fig.5. Comparison of vertical forces acting on right-fore unit of landing gear of helicopter during landing with different vertical speed, moment of touch down at the 20th rotor revolution, after the 40th revolution - rotor speed was slowed : a) the case of landing vertical speed of $1 \mathrm{~m} / \mathrm{s}$; b) soft landing with low vertical speed equal to $0.1 \mathrm{~m} / \mathrm{s}$ [author]

In Fig. 6 are shown the time-runs of blade lagging angles for landing with different initial vertical speed and following quick or slow rate of rotor speed decrease. For the case of moderate speed of landing and low rate of rotor speed reduction (Fig. 6c), the sharp growth of lagging oscillations are observed between the 60 th and the 100th rotor revolution. Mutual increase of blade lagging and fuselage motion (Fig. 8) is an evidence of resonance phenomenon which can give the arise of oscillations if frequency of forcing loads passes near a resonant frequency for enough term of time. The enlarged motion of fuselage results in generation the landing gear loads of value higher than at moment of touchdown (Fig. 7b). The comparison of the quick and slower rate decrease of the main rotor rotational speed is shown in Fig. 7a. 

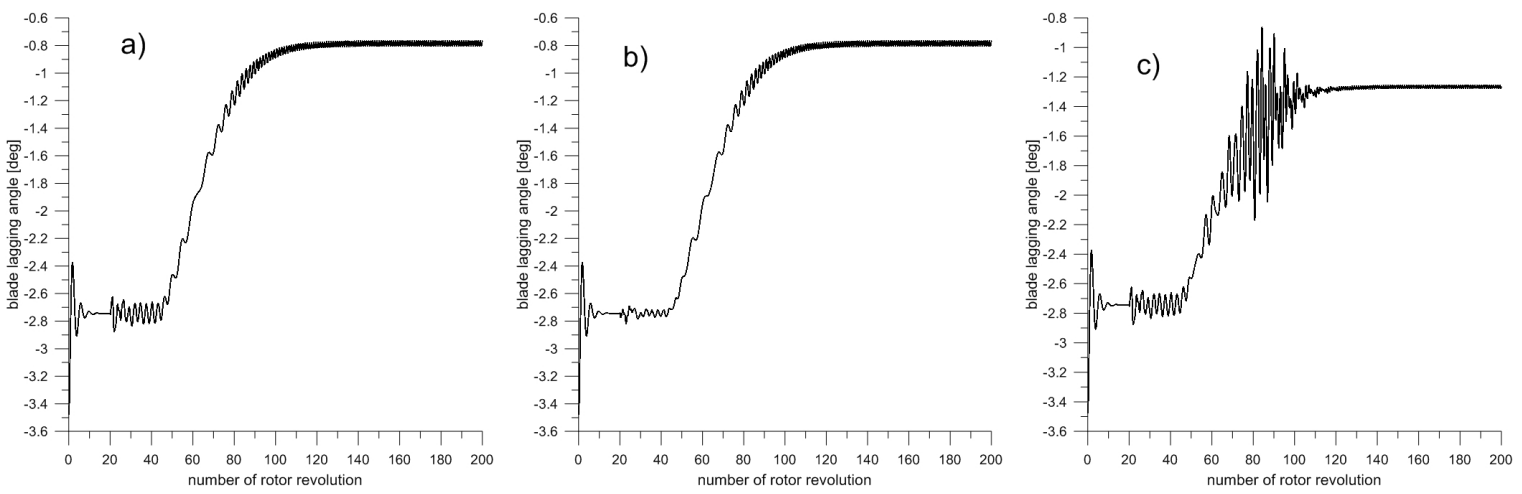

Fig.6. Comparison of time-runs of rotor blade lagging angles for landing with different vertical speed, the 20 th rotor revolution - moment when landing gear touched ground, rotor speed was slowed after the 40th rotor revolution: a) the case with initial vertical speed of helicopter equals $1 \mathrm{~m} / \mathrm{s}$ and with high rate of rotor rotational speed decrease; b) soft landing with vertical speed of $0.1 \mathrm{~m} / \mathrm{s}$ and high rate of rotor speed decrease; c) landing with initial vertical speed of helicopter equals $1 \mathrm{~m} / \mathrm{s}$ and low rate of rotor rotational speed decrease [author]
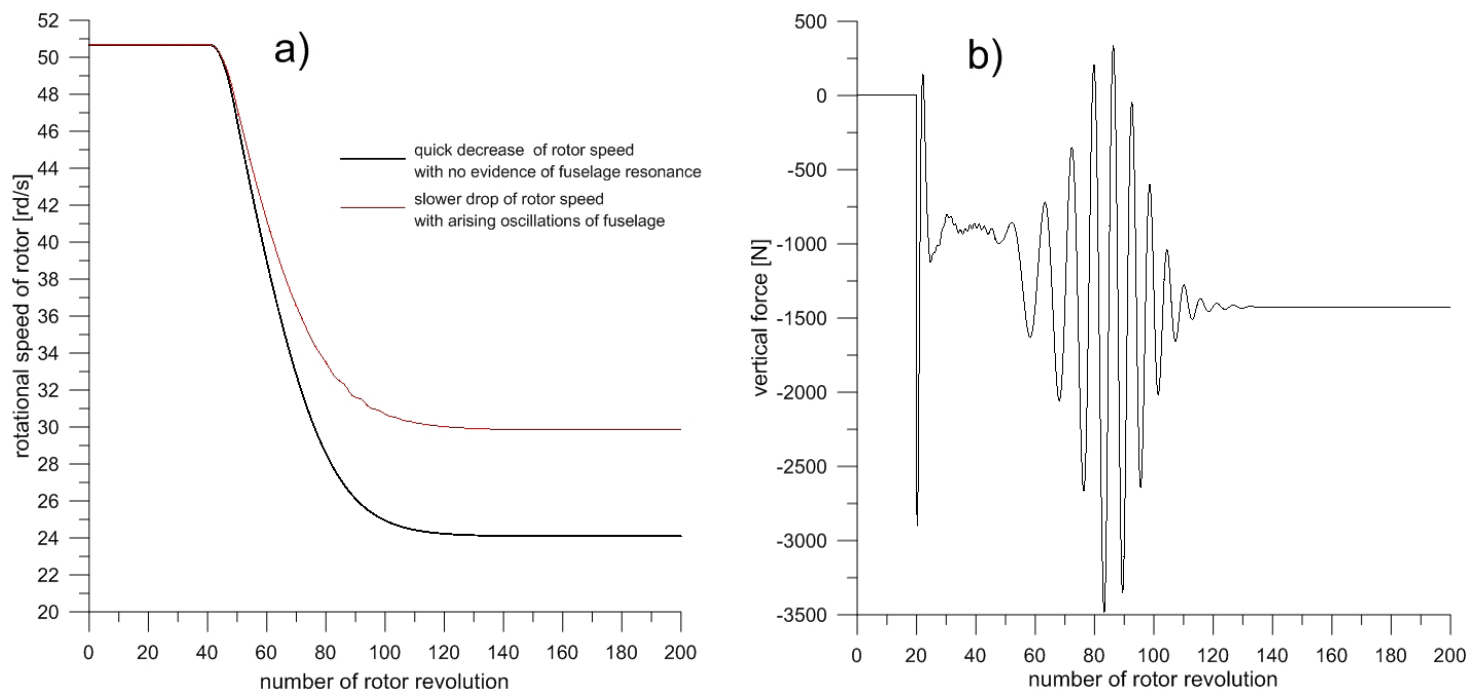

Fig.7. Comparison (a) of rotor speed plots for the cases of quick and slower rate of rotational speed decrease after touch-down with vertical speed of $1 \mathrm{~m} / \mathrm{s}$, (b) time-run of the vertical force at the right-fore unit of the landing gear during slow drop of rotor speed after touch-down with vertical speed of $1 \mathrm{~m} / \mathrm{s}$ (see Fig.5a) [author]

The results of calculation for the case of take-off include time-runs of the main rotor thrust (Fig. 9a), power required to drive main rotor (Fig. 9b), parameters of rotor blade motion - blade lagging angle (Fig. 10) and out-of-plane deflection at blade tip (Fig. 11), components of fuselage motion (Fig. 12) and forces of landing gear (Fig. 13). The simulation consists of following phases which happen or may occur before helicopter take-off. The simulation started with initial steady position of rotor shaft axis with low rotor rotation speed equal to $60 \%$ of its nominal value and with low level of blade collective pitch angle. After the 20th rotor revolution, motion of fuselage and gearbox on their supports 
is allowed. Next, between the 40th and 100th revolution the rotor rotational speed was increased up to nominal value with constant low blade collective pitch. At the 120th rotor revolution the forward wind gust was introduced with its velocity arising to $9 \mathrm{~m} / \mathrm{s}$. From the 140th rotor revolution the blade collective pitch was gradually increased to the higher by $1^{\circ}$ value. Then the constant conditions of rotor speed wind gust and collective pitch were kept to the end of simulation.
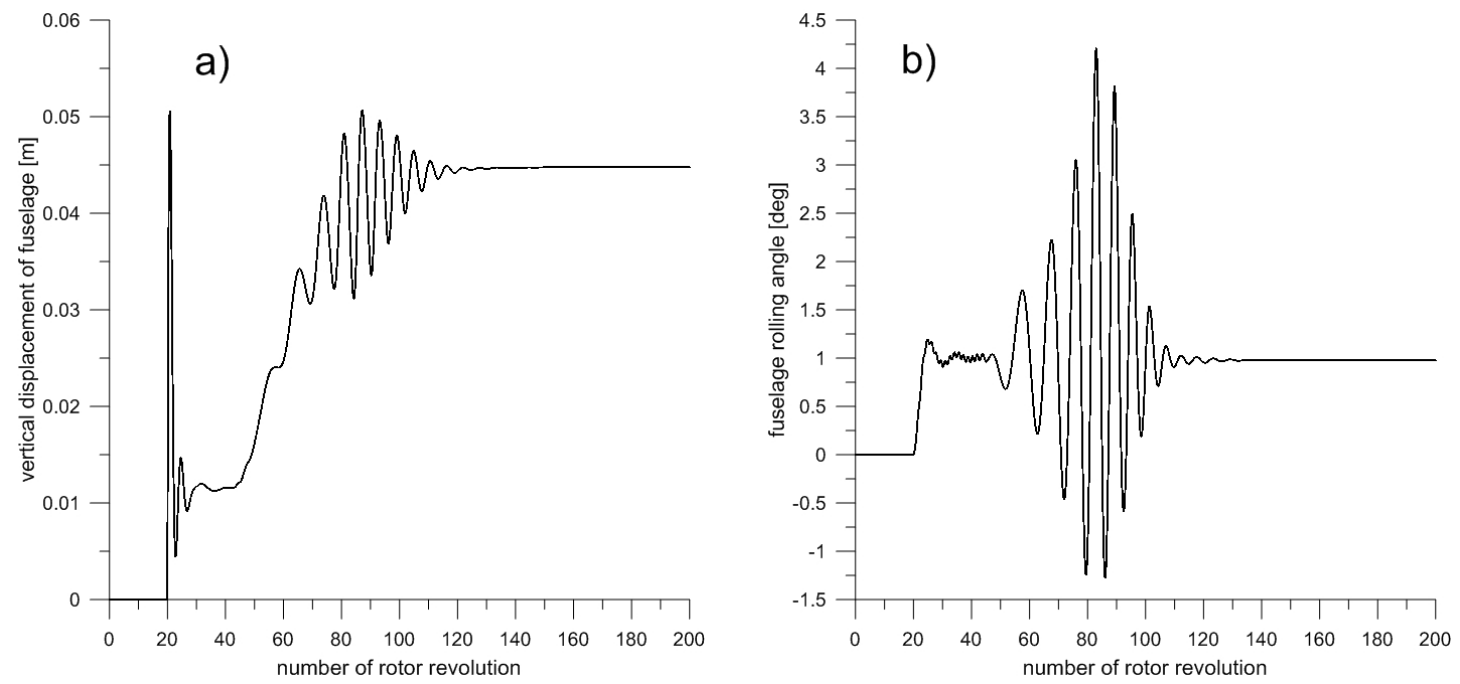

Fig.8. Helicopter fuselage displacements on elastic landing gear after touch-down with vertical speed equal $1 \mathrm{~m} / \mathrm{s}$ during slow rate of rotor speed decrease: a) vertical displacements of the fuselage mass centre;

b) rolling angle of fuselage [author]
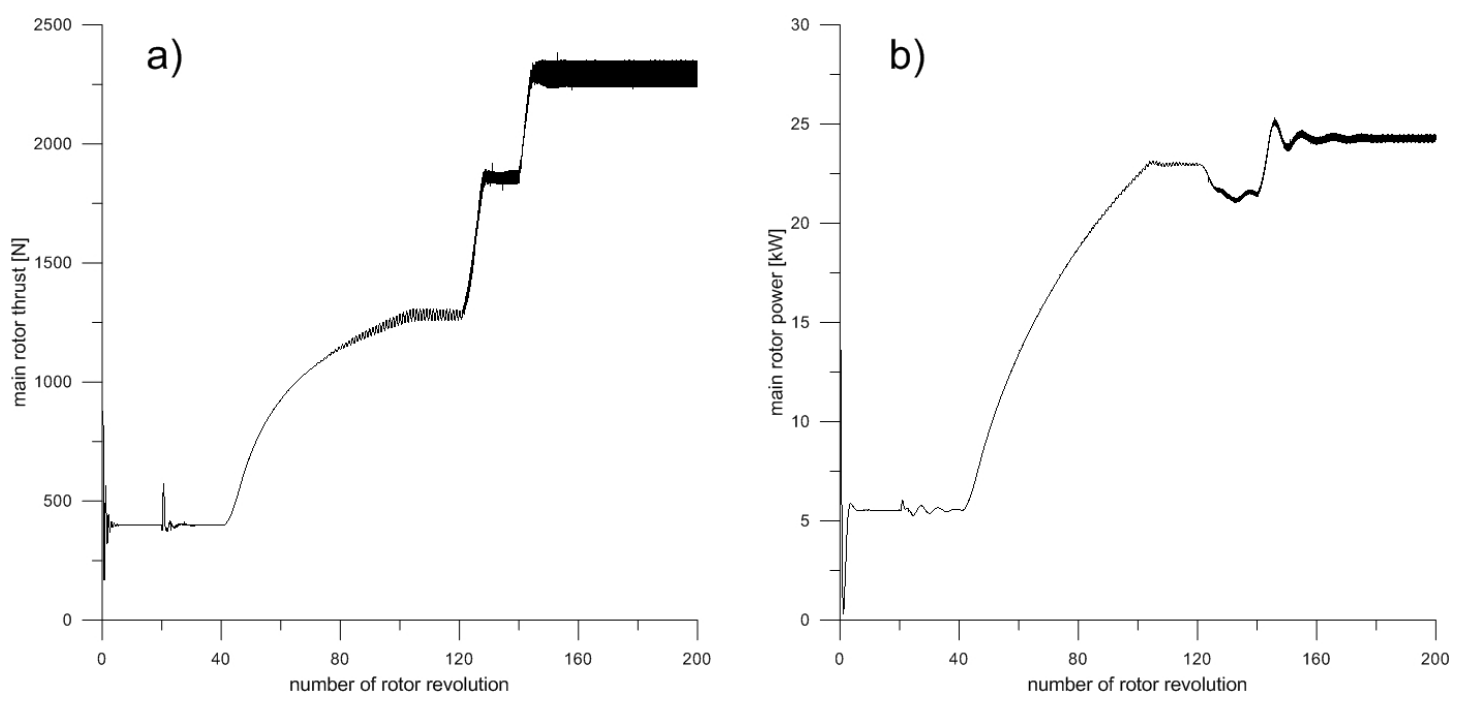

Fig.9. Changes of main rotor thrust (a) and power required to drive main rotor (b) for the cases before the take-off : phase of increasing the rotor rotational speed up to the nominal value with the blade collective pitch kept constant (the 40th-100th revolutions); the case of wind gust (the 120th-140th revolutions) ; the range of increased by $1^{\circ}$ value of blade collective pitch (the 140th-200th revolutions) [author] 

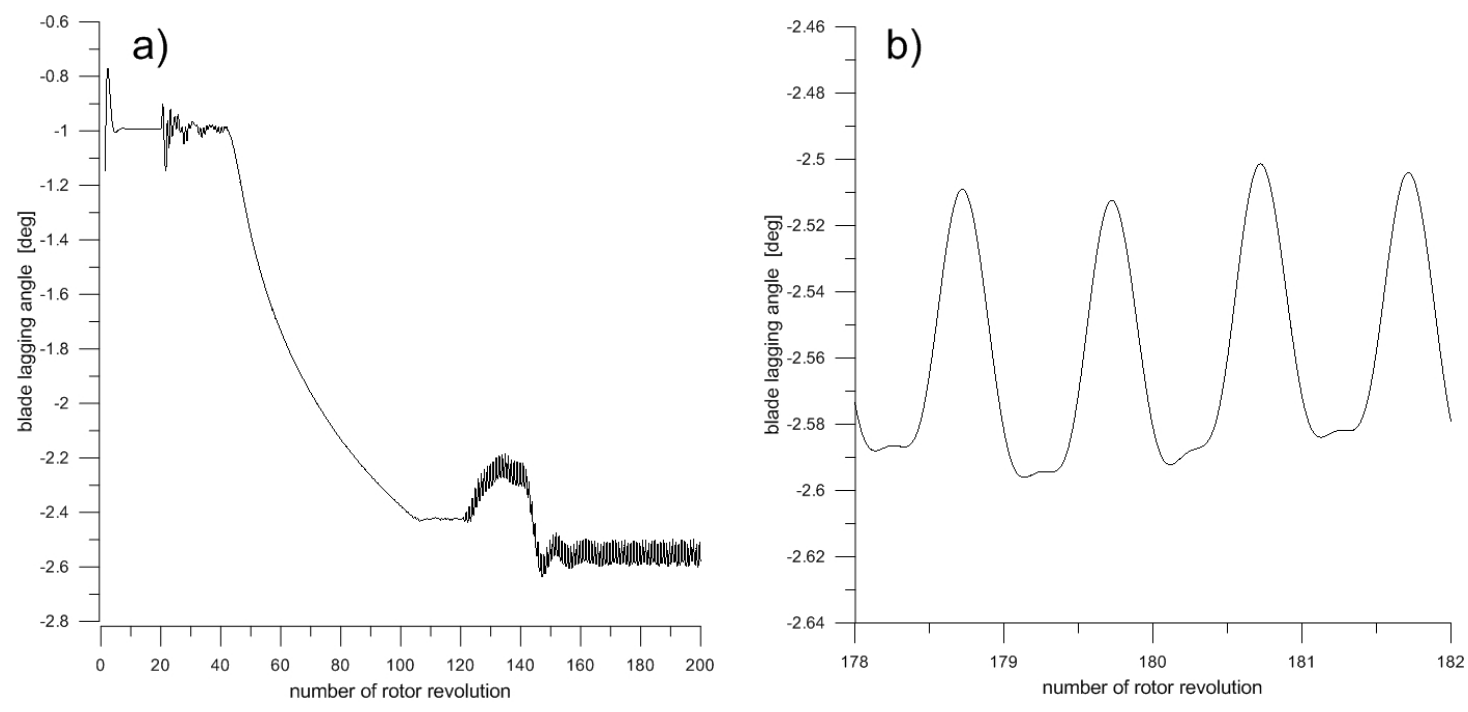

Fig.10. Blade lagging angle before the take-off :a) the full time-run for phase of increasing the rotor speed, wind gust and part with blade collective pitch increased by $1^{\circ} ; \mathrm{b}$ ) enlarged fragment between 178th and 182 nd rotor revolution for increased blade collective pitch [author]

As it can be noticed in Fig.9, increase of rotor speed resulted in gradually arising value of rotor thrust and power required to drive the rotor. Occurrence of wind gust (after 120th revolution) changed the local flow conditions of rotor blades which caused increase of rotor thrust with simultaneous decrease of rotor required power. Following after the 140th rotor revolution increase of blade collective pitch allowed to generate higher thrust but with larger power applied.

The effects of wind gust can be observed in plots of blade motion parameters, lagging angle (Fig. 10) and bending out-of-plane deflection (Fig. 11). The wind gusts influence on generation the variable loads and deflections of rotor blades which correspond with changes of angles of attack and components of local air-flow dependent on azimuthal position of blades relative to the direction of wind.

Increased rotor thrust enables fuselage to rise up on the deflected landing gear units (Fig. 12). The effects of the rotor thrust changes are observed in plots of landing gear forces (Fig. 13) which are getting fall down as rotor thrust is rising. The differences in force levels at the front and rear units of landing gear are related with position of helicopter center of mass which is located closer to the rear unit. 

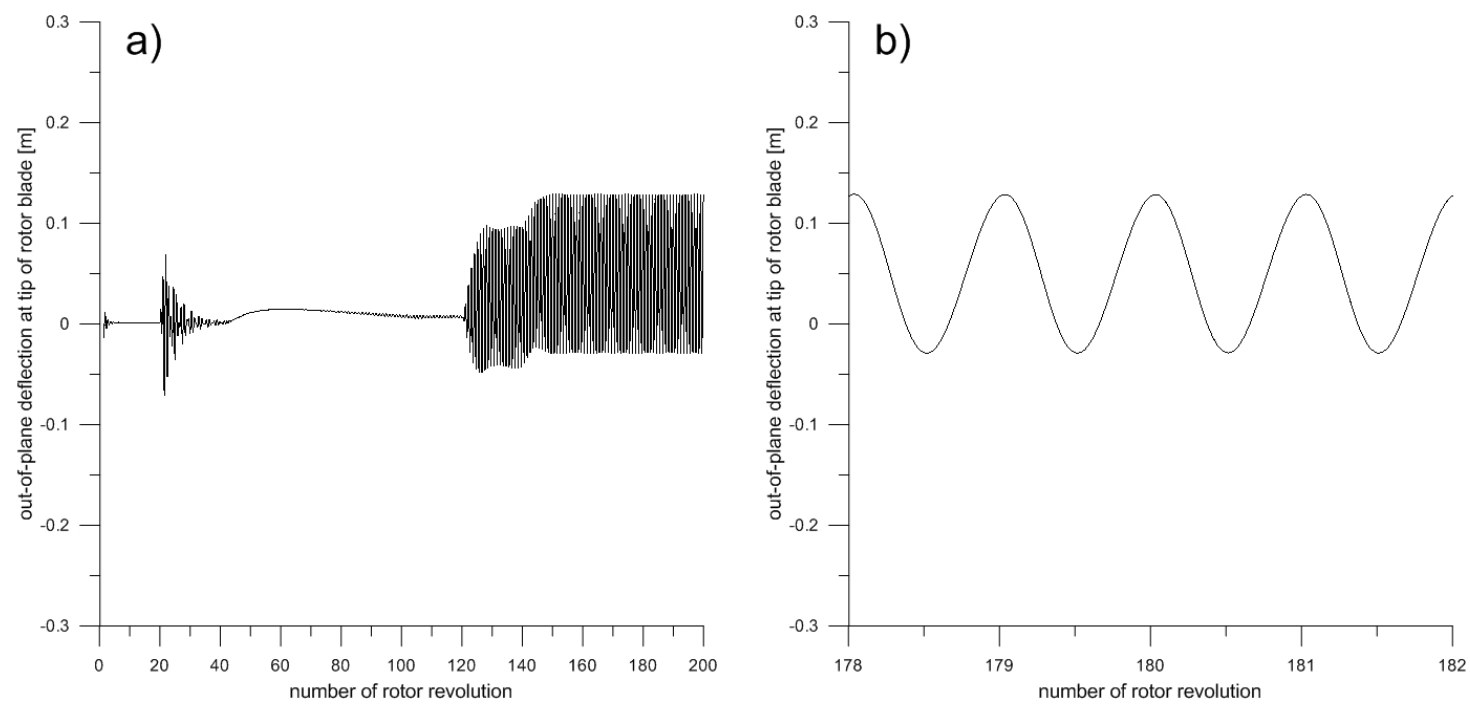

Fig.11. Out-of-plane deflection at tip of rotor blade before the take-off :a) full plot includes the phase of rotor speed increase, wind gust and range with blade collective pitch increased by $1^{\circ} ; \mathrm{b}$ ) enlarged fragment between 178th and 182nd rotor revolution for the increased blade collective pitch [author]
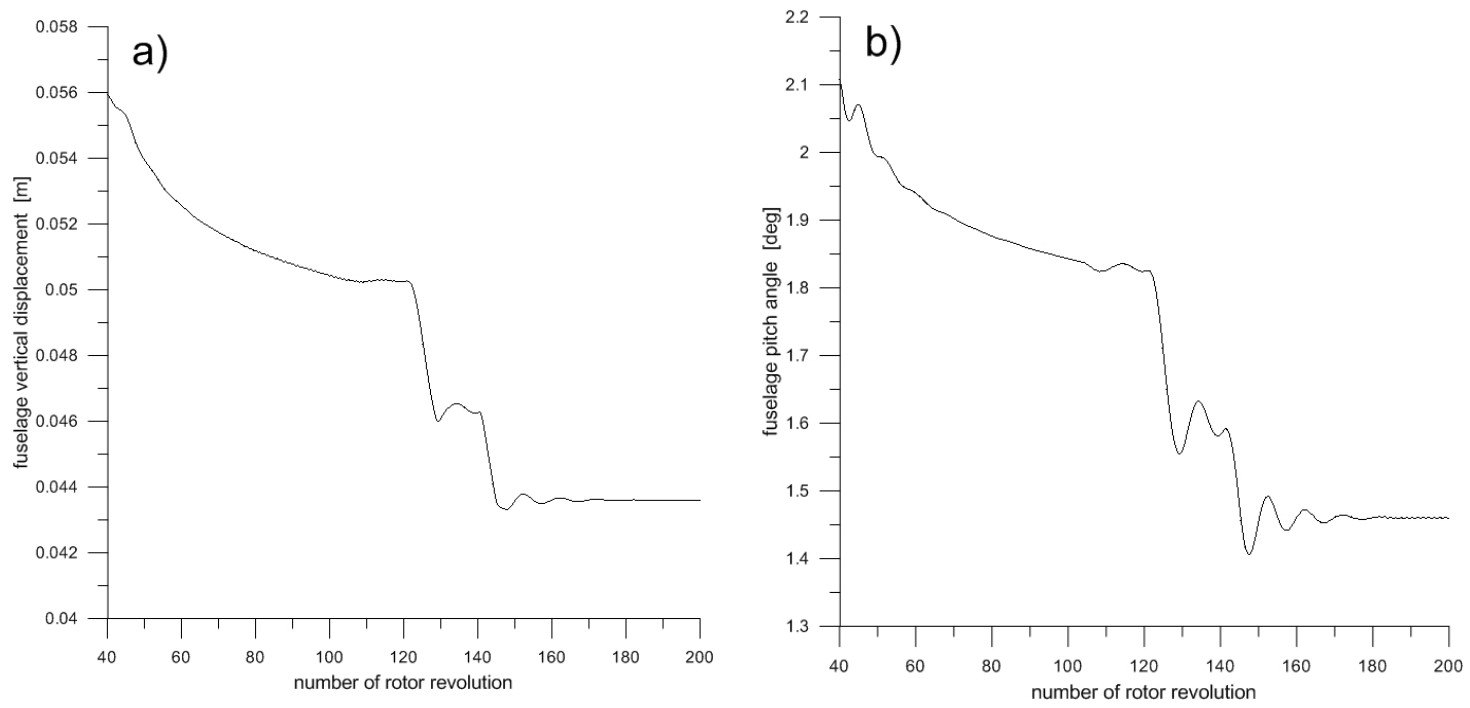

Fig.12. Displacements of helicopter fuselage before the take-off during rotor speed-up, wind gust and increasing collective pitch by $1^{\circ}$ : a) vertical displacement of fuselage centre of mass; b) fuselage pitch angle [author] 

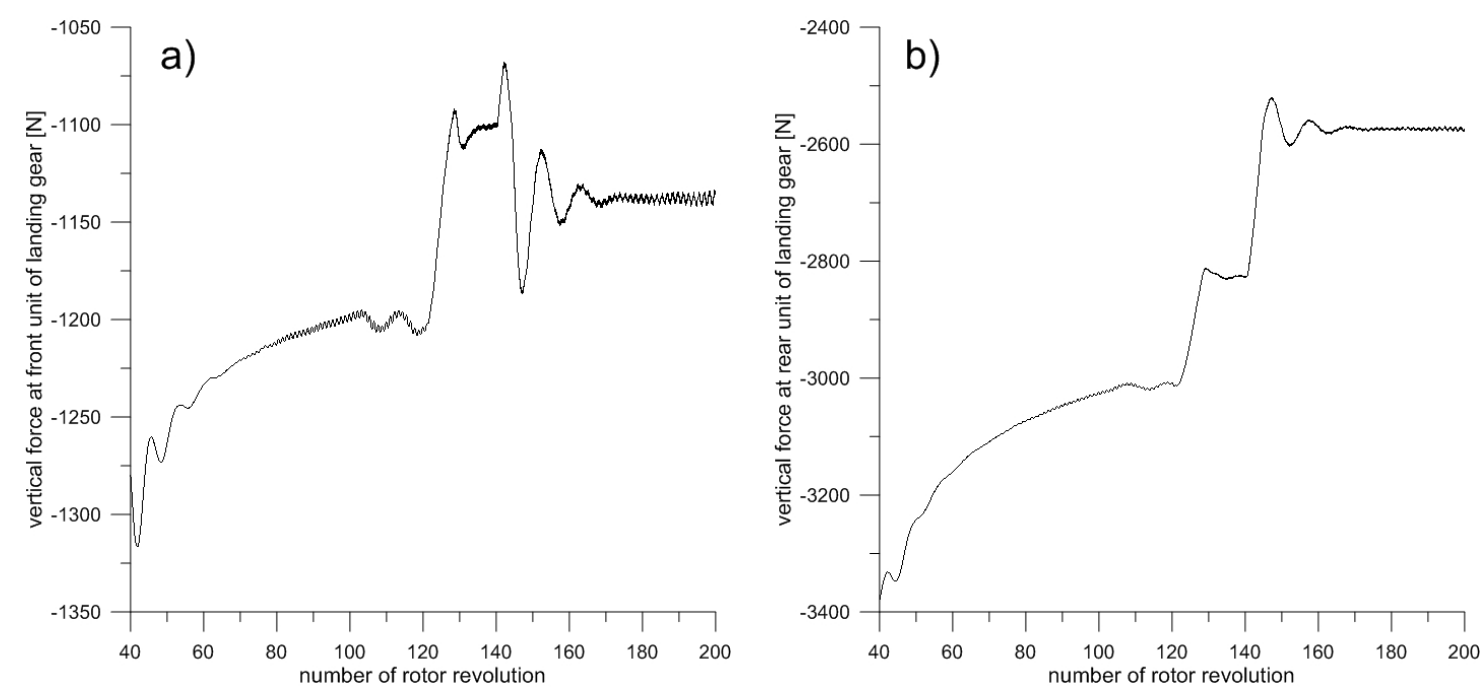

Fig.13. Vertical forces at units of helicopter landing gear before the take-off during rotor speed-up, wind gust and collective pitch increasing by $1^{\circ}:$ a) force at right front unit of landing gear;

b) force at left rear unit of landing gear [author]

Some view on loads generated at landing site by helicopter standing on ground with rotating rotor can be observed in plot of acceleration recorded on board of the EC-135 (Fig.14) during maintenance tests of landing and take-off operation (Fig.15). The registration were recorded with rate of 2 samples per second which is too low to find the loads in shorter time range at the moment of touchdown. The access to selected set of board registrations of the EC-135 helicopter was possible thanks to courtesy of Maintenance Manager of Polish Medical Air Rescue (LPR).

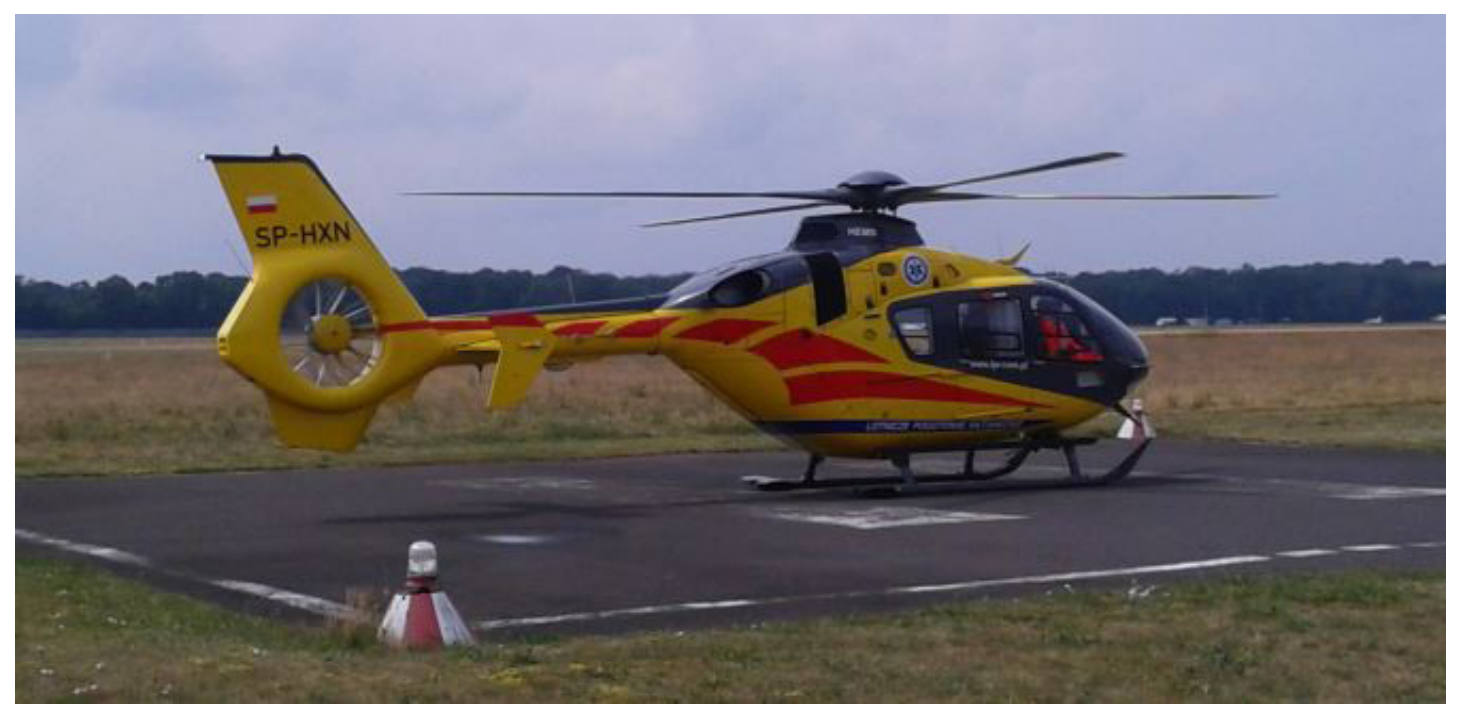

Fig.14. The EC-135 helicopter of Polish Medical Air Rescue (LPR -Lotnicze Pogotowie Ratunkowe) [author] 

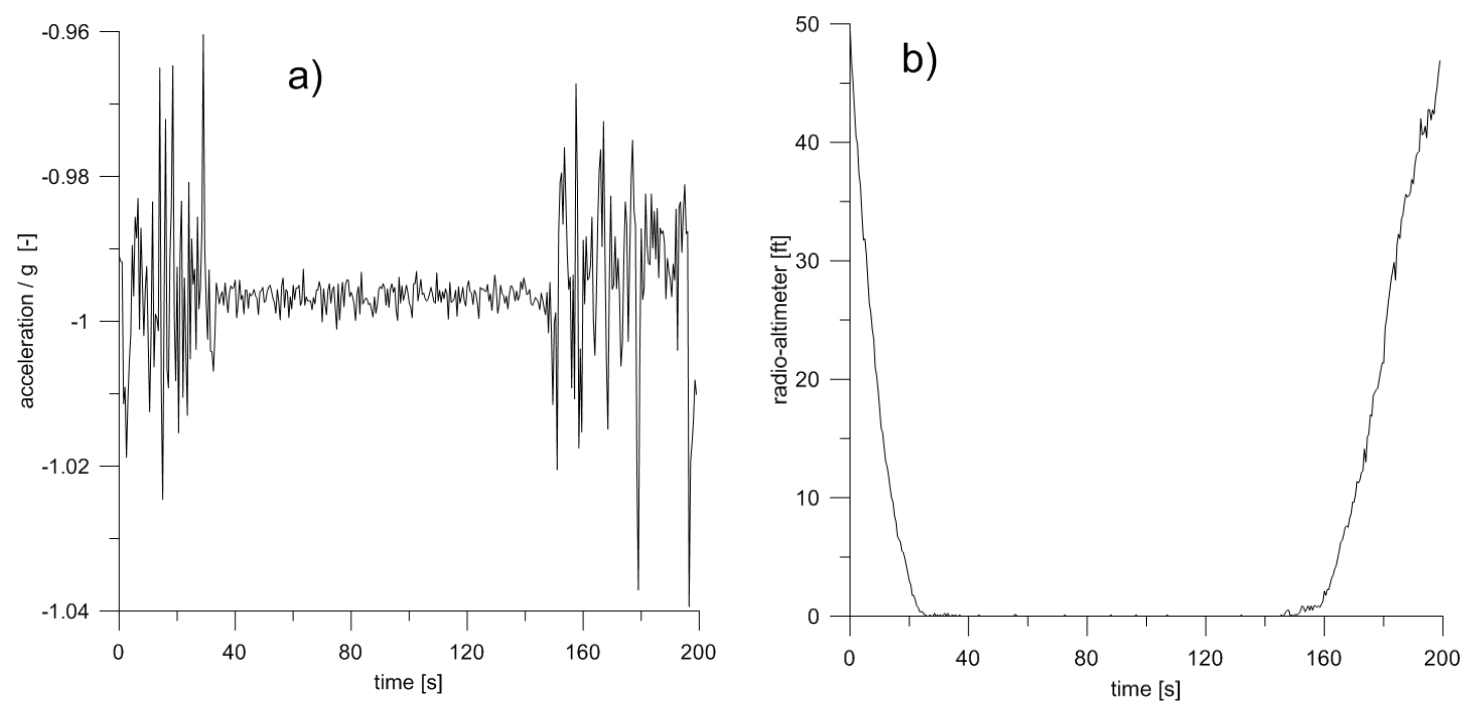

Fig.15. Board recorder registration of the EC-135 helicopter during landing and take-off operation: a) acceleration of helicopter mass centre, b) height over ground [author]

\section{CONCLUSIONS}

The simulation program can be applied for predicting behavior of the helicopter standing on ground with rotating rotor during take-off or landing.

The simulation calculations may help to collect information related to loads of landing site generated by helicopter in different conditions of rotorcraft operations.

Results of calculation of loads at landing sites with introduced effects of helicopter dynamics may be useful for more precisely definition of the conditions for designing the heliports and helipads.

Simulations can help in formulation the envelope of safety boundaries of helicopter operations.

\section{REFERENCES}

[1] https://www.rega.ch/en/about-us/history/1946-1959.aspx, access: 19.10.18.

[2] http://www.samolotypolskie.pl/samoloty/2707/126/SM-12, access: 19.10.18.

[3] Heliport Manual, 1995, Doc 9261-AN/903, ICAO publication.

[4] Smith R.D., 1994, "Safe Heliports Through Design and Planning. A Summary of FAA Research and Development", Report FAA No. DOT/FAA/93/17, Washington.

[5] FAA, 2012, Advisory Circular AC 150/5390-2C, Heliport Design.

[6] Wojewódzki B., Gulańczyk K., Muzolf P., 2015, "Koncepcja lądowiska dla śmigłowca lotniczego pogotowia ratunkowego" (Eng.: "The concept of landing fields for medical air rescue helicopters"), Logistyka-Nauka, No. 4 , pp. 6793-6804, (published in electronic format on CD 2), Poznań.

[7] Wąchalski K., 2016, "Ocena uwarunkowań konstrukcyjnych wyniesionych lądowisk dla helikopterów na budynkach szpitalnych realizowanych obecnie w Polsce", (Eng.: "Assessment of the current construction conditions for elevated helipad on hospital buildings in Poland"), Transactions of the Institute of Aviation, No. 3(244), pp. 189-201, Warsaw. 
[8] Civil Aviation Authority, 2016, Standards for helicopter landings areas at hospitals, CAP 12643, Gatwick Airport South, West Sussex.

[9] Dziubiński A., 2016, "CFD analysis of wind direction influence on rooftop helipad operations safety", Transactions of the Institute of Aviation, No. 1(242), pp. 23-35.

[10] Dziubiński A., 2016, "CFD analysis of rotor wake influence on rooftop helipad operations safety", Transactions of the Institute of Aviation, No. 1(242), pp. 7-22.

[11] Cieślak S., 2018, „Ocena oddziaływania wirnika nośnego śmigłowca na otoczenie” (Eng.:”Evaluation of helicopter main rotor influence on environment"), XIII Krajowe Forum Wiropłatowe, Warsaw, Poland, 29 June.

[12] Ruchała P., Stryczniewicz W., Zalewski W., Krysztofiak G., Dziubiński A., Wojtas M., Szumański K., 2018, „Eksperymentalne i numeryczne metody badań niestacjonarnego oddziaływania strumienia podwirnikowego na płytę lądowiska” (Eng.: „Experimental and numerical investigation methods of rotor unsteady downwash influence on helipad Surface”), XIII Krajowe Forum Wiroplatowe, Warsaw, Poland, 29 June.

\section{SYMULACYJNY MODEL DO WYZNACZANIA OBCIĄŻEŃ POWIERZCHNI LĄDOWISKA W TRAKCIE STARTU LUB LĄDOWANIA ŚMIGŁOWCA}

\section{Streszczenie}

W pracy przedstawiono metodę symulacyjną wyznaczania obciążeń lądowiska generowanych przez podwozie śmigłowca w fazie startu lub lądowania. Przy wirującym wirniku wielkość obciążenia podwozia śmigłowca może zmieniać się w zależności od parametrów ruchu śmigłowca w momencie zetknięcia podwozia z podłożem, sterowaniem kątem nastawienia łopat, wystąpieniem podmuchów. Rozważany model fizyczny śmigłowca składa się z kadłuba i przekładni głównej traktowanych jako ciała sztywne połączone elementami sprężystymi. Kadłub podparty jest na podwoziu modelowanym przez układ elementów sprężystych i tłumiących. Łopaty wirnika nośnego zastąpiono osiami elastycznymi z rozmieszczonymi wzdłuż nich masami skupionymi segmentów łopat. Do rozwiązania równań ruchu modelu śmigłowca zastosowano metodę Runge-Kutta. Zgodnie z metodą Galerkina przyjęto, że parametry ruchu odkształcalnych łopat można traktować jako złożenie uwzględnianych giętnych i skrętnych postaci własnych. Do obliczeń symulacyjnych wykorzystano dane hypotetycznego śmigłowca lekkiego. Przedstawiono symulacyjne wyniki dotyczące zachowania się śmigłowca w trakcie zetknięcia się z podłożem oraz dotyczące zmian obciążeń wirnika i podwozia przy wystąpieniu podmuchów lub wprowadzeniu sterowaniu skokiem łopat wirnika nośnego. Metoda symulacyjna może być przydatna przy określeniu granic bezpiecznej eksploatacji śmigłowca

Słowa kluczowe: śmigłowiec, lądowisko, obciążenia podwozia. 